\title{
Pengaruh Pembangunan Desa dan Faktor Faktor yang Menghambat Pengelolaan Alokasi Dana Desa Terhadap Akuntabilitas Publik Pengelolaan Dana Desa
}

\author{
${ }^{1}$ Wikan Budi Utami, ${ }^{2}$ Ketut Wahyu Ibrahim \\ ${ }^{1,2}$ Sekolah Tinggi Ilmu Ekonomi AAS Surakarta, Indonesia \\ ${ }^{1}$ Email korenpondensi: budiutamiwikan@gmail.com
}

\begin{abstract}
Allocation of village founds is financial budget that given to village by government, the source from local tax profit sharing and balanced founds center and local financial received by district. The purpose of this research is determine the effect of village development and factors can be hamper allocation of village founds management on public accountability allocation of village management. The population of this research are villager of Purwosari and the paper uses a sampel are 30 person villager of Purwosari. The sampling technique which is used to get the sample is purposive sampling. Methods of data collection in this research used questionare. Data analysis used descriptive statistical analysis and multiple linier regressions. The data were processed using SPSS 21. The research show that the village development and factors can be hamper allocation of village founds management take effect to publik accountability allocation of village founds management.
\end{abstract}

Keywords: allocation of village founds, village development, factors can be hamper allocation of village founds management, public accountability allocation of village founds managemet

Saran sitasi: Utami, W., \& Ibrahim, K. (2019). Pengaruh Pembangunan Desa dan Faktor Faktor yang Menghambat Pengelolaan Alokasi Dana Desa Terhadap Akuntabilitas Publik Pengelolaan Dana Desa. Jurnal Akuntansi dan Pajak, 20(1), 36-42. doi: http://dx.doi.org/10.29040/jap.v20i1.551

DOI: http://dx.doi.org/10.29040/jap.v20i1.551

\section{Pendahuluan}

Menurut Widjaja (2010) otonomi daerah adalah kewenangan daerah. Otonomi untuk mengatur dan mengurus kepentingan masyarakat setempat menurut prakarsa sendiri berdasarkan aspirasi masyarakat, sesuai dengan peraturan dan perundang-undangan. Pemberian kewenangan dan keleluasaan kepada daerah untuk mengelola dan memanfaatkan sumber daya daerah secara optimal adalah makna lain dari pemberian otonomi daerah. Pemberian wewenang dan keleluasaan yang luas tersebut harus disertai dengan pengawasan yang kuat, untuk mengantisipasi supaya tidak terjadi penyimpangan dan penyelewengan. Secara esensi sebenarnya otonomi/kemandirian harus dimulai dari level pemerintahan ditingkat paling bawah, yaitu desa tapi pada kenyataannya titik berat otonomi diletakkan pada tingkat kabupaten/kota. Selama ini pendapatan asli desa dan swadaya masyarakat yang jumlah maupun sifatnya tidak dapat diprediksi, masih menjadi andalan sumber pembangunan desa.

Sampai saat ini masih banyak daerah yang belum melakukan Alokasi Dana Desa (ADD), meski telah diwajibkan untuk dianggarkan di pos APBD. Seharusnya proses transformasi kearah pemberdayaan desa terus menerus dilaksanakan dan semua elemen didorong untuk menuju otonomi desa. Keberhasilan otonomi desa sangat 
bergantung kepada Alokasi Dana Desa. Efektivitas dan efisien penyaluran Alokasi Dana Desa (ADD) dari pemerintah kabupaten/kota ke pemerintah desa serta bagaimana pemanfaatan dana tersebut menjadi sangat penting, karena keduanya merupakan parameter paling sederhana bagi keberhasilan desentralisasi. Pengelolaan Alokasi Dana Desa tersebut masih belum maksimal sesuai dengan tujuan Alokasi Dana Desa (ADD). Tujuan dari Alokasi Dana Desa (ADD) adalah untuk membiayai program pemerintah desa dalam melaksanakan kegiatan pemerintah dan pemberdayaan masyarakat, sehingga kesempatan bekerja, pemerataan pendapatan, dan kesempatan bekerja dan berusaha bagi masyarakat desa dapat ditingkatkan. Hal ini dikarenakan kurangnya pemberdayaan yang dilakukan kepada masyarakat dan tidak adanya pengembangan sosial budaya yang dilakukan karena yang tampak dari pelaksanaan Alokasi Dana Desa (ADD) hanyalah pengadaan barang dan pengadaan pupuk tanam.

Kepala desa adalah penanggung jawab dari pengelolaan keuangan desa secara keseluruhan. Dalam PP No. 43 tahun 2014 pasal 103-104 mengatur tata cara pelaporan yang wajib dilakukan oleh kepala desa. Kepala desa wajib melaporkan laporan realisasi pelaksanaan Anggaran Pendapatan dan Belanja Desa (APBD) kepada bupati/walikota setiap semester tahun berjalan. Kepala desa juga berkewajiban menyampaikan laporan pertanggungjawaban pelaksanaan Anggaran Pendapatan dan Belanja Desa (APBD) kepada bupati/walikota setiap akhir tahun anggaran. Laporan yang dibuat kepala desa ditujukan kepada bupati/walikota yang disampaikan melalui camat. Dalam pembangunan desa tentunya ada perencanaan, pengelolaan serta tanggung jawab yang sebesar besarnya dari pihak yang dipercaya. Pemerintah desa haruslah menerapkan akuntabiltas publik saat melaksanakan pembangunan desa, agar terbangun kepercayaan dari masyarakat agar proses pembangunan desa tidak terganggu dan tidak terhambat.
Sumber daya manusia merupakan faktor yang penting bagi setiap usaha. Sumber daya manusia yang berkualitas akan menentukan kejayaan atau kegagalan dalam persaingan (Tambunan, 2003:15). Diperlukan sumber daya manusia yang terampil dan dapat dipercaya agar upaya mencapai efektivitas akuntabilitas publik terhadap alokasi dana desa. Menurut Handoko (2012) efektivitas adalah kemampuan untuk memilih tujuan yang tepat untuk mencapai tujuan yang telah ditetapkan. Kesadaran masyarakat diperlukan dalam mengawal akuntabilitas publik terhadap pengelolaan dana desa. Tanpa adanya kesadaran dari masyarakat maka upaya ini tidak akan berjalan dengan baik. Upaya meningkatkan kesadaran masyarakat desa dalam menerapakan akuntabilitas publik, dengan cara pemerintah memberikan informasi yang tepat dan benar serta mudah di mengerti masyarakat. Latar belakang pendidikan masyarakat penduduk desa bermacam-macam tingkatan sehingga informasi yang disampaikan pemerintah desa harus singkat dan mudah dimengerti oleh seluruh lapisan masyarakat. Pelaksanaan transparansi penggunaan alokasi dana desa di beberapa desa belum dilaksanakan, seperti halnya di Desa Purwosari, Kecamatan Kwadungan, Kabupaten Ngawi belum dilaksanakan dengan baik.

Penelitian dengan topik yang sama telah dilakukan oleh beberapa peneliti dengan hasil yang berlainan. Novindra Dwi Setiana dan Nur Laila Yuliani melakukan penelitian dengan judul Pengaruh Pemahaman dan Peran Perangkat Desa Terhadap Akuntabilitas Pengelolaan Dana Desa dengan hasil Peran perangkat desa dan dan pemahaman perangkat desa dalam menjelaskan akuntabilitas pengelolaan dana desa kurang berpengaruh dibandingkan faktor lain. Novi Anti Ruru, Novi S. Bodiarso, Lintja Kalagi melakukan penelitian dengan judul Analisis Penerapan Alokasi Dana Desa (ADD) dalam upaya Meningkatakan Pembangunan Desa (Desa Suwaan, Kecamatan Kalawat, Kabupaten Minahasa Utara). Hasil penelitiannya sebagai berikut: Transparansi dalam pelaporan pengalokasian desa dan partisipasi masyarakat berpengaruh dalam efektivitas akuntabilitas pengelolaan dana desa. 
Berdasarkan latar belakang di atas, maka peneliti tertarik untuk membuat penelitian dengan judul Pengaruh Pembangunan Desa dan Faktor-Faktor Yang Menghambat Pengelolaan Alokasi Dana Desa Terhadap Akuntabilitas Publik Pengelolaan Alokasi Dana Desa (Studi Kasus di Desa Purwosari, Kwadungan, Ngawi).

\section{Metode Penelitian}

Sesuai dengan judul penelitian ini maka penelitian dilaksanakan di Desa Purwosari, Kecamatan Kwadungan, Kabupaten Ngawi.Waktu penelitian dilaksanakan pada bulan Mei 2018. Jenis penelitian yang akan dilakukan adalah jenis penelitian kualitatif yaitu bertujuan untuk mengetahui bagaimana pengaruh pembangunan desa dan faktor-faktor yang menghambat pengelolaan Alokasi Dana Desa (ADD) terhadap akuntabilitas publik pengelolaan Alokasi Dana Desa (ADD) di Desa Purwosari Kecamatan Kwadungan Kabupaten Ngawi. Populasi yang ditetapkan oleh peneliti dalam penelitian ini, yaitu warga masyarakat Desa Purwosari, Kecamatan Kwadungan, Kabupaten Ngawi. Penarikan sample metode purposive sampling. Sugiyono (2017) berpendapat bahwa purposive sampling adalah teknik penentuan sampel dengan pertimbangan tertentu. Kriteria sampel dalam penelitian ini sebagai berikut: perangkat desa, tokoh masyarakat, serta masyarakat Desa Purwosari, Kecamatan Kwadungan, Kabupaten Ngawi yang berusia diatas 30 tahun. Dari kriteria tersebut diperoleh sampel penelitian sebanyak 30 .

\subsection{Teknik Analisis Data}

\subsubsection{Uji Validitas}

Menurut Arikunto (2013) validitas adalah suatu ukuran yang menunjukan tingkat-tingkat kevalidan dan kesahihan suatu instrumen.Suatu instrumen yang valid atau sahih mempunyai validitas tinggi, sebaliknya instrumen yang kurang valid berarti mempunyai validitas rendah.

\subsubsection{Uji Reliabilitas}

Menurut Sugiyono (2017) uji reliabilitas dilakukan untuk mengetahui seberapa jauh hasil pengukuran tetap konsisten apabila dilakukan pengukuran dua kali atau lebih terhadap gejala yang sama dengan menggunakan alat pengukur sama.

\subsection{Uji Hipotesis}

\subsubsection{Uji t}

Menurut Ghozali (2016) uji beda t-test digunakan untuk menguji seberapa jauh pengaruh variabel independen yang digunakan dalam penelitian ini secara individual dalam menerangkan variabel dependen secara parsial. Uji t digunakan untuk menguji pengaruh variabel pembangunan desa $\left(\mathrm{X}_{1}\right)$ terhadap akuntabilitas publik pengelolaan Alokasi Dana Desa (ADD) di Desa Purwosari, Kecamatan Kwadungan, Kabupaten Ngawi (Y). Serta menguji pengaruh variabel faktor-faktor yang menghambat pengelolaan alokasi dana desa $\left(\mathrm{X}_{2}\right)$ terhadap akuntabilitas publik pengelolaan Alokasi Dana Desa (ADD) di Desa Purwosari, Kecamatan Kwadungan, Kabupaten Ngawi(Y). Pada variabel bebas dapat dikatakan berpengaruh signifikan terhadap variabel terikat apabila jika nilai probabilitas signifikansi $<0,05$, maka hipotesis diterima

\subsubsection{Uji F}

Menurut Ghozali (2016) uji statistik F pada dasarnya menunjukkan apakah semua variabel independen atau variabel bebas yang dimasukkan dalam model mempunyai pengaruh secara bersama-sama terhadap variabel dependen atau variabel terikat. Dalam penelitian ini uji $\mathrm{F}$ digunakan untuk menguji variabel pembangunan desa $\left(\mathrm{X}_{1}\right)$ dan variabel faktor-faktor yang menghambat pengelolaan alokasi dana desa $\left(\mathrm{X}_{2}\right)$ terhadap akuntabilitas publik pengelolaan Alokasi Dana Desa (ADD) di Desa Purwosari, Kecamatan Kwadungan, Kabupaten Ngawi(Y) secara simultan. Apabila nilai sig $<0,05$ berarti secara simultan ada pengaruh yang signifikan variabel independen terhadap variabel dependen dan sebaliknya apabila nilai sig $>0,0$, berarti secara simutan terdapat pengaruh tidak signifikan variabel independen terhadap variabel dependen. 


\section{Jurnal Akuntansi dan Pajak, 20(01), 2019, 39}

\subsubsection{Koefisien Determinasi}

Menurut Ghozali (2016) koefisien determinasi $\left(\mathrm{R}^{2}\right)$ merupakan alat untuk mengukur seberapa jauh kemampuan model dalam menerangkan variasi variabel dependen. Nilai $R^{2}$ yang kecil berarti kemampuan variabel-variabel independen dalam menjelaskan variasi variabel dependen amat terbatas. Sebaliknya jika nilai yang mendekati 1 berarti variabel-variabel independen memberikan hampir semua informasi yang dibutuhkan untuk memprediksi variabelvariabel dependen.

Tabel 1

Hasil Uji Validitas

\begin{tabular}{|c|c|c|c|c|}
\hline Variabel & Pertanyaan & $\begin{array}{c}\text { Corrected item total } \\
\text { correlation }\end{array}$ & $\mathbf{R}$ tabel & Ket. \\
\hline \multirow[t]{19}{*}{ Pembangunan Desa } & 1 & 0,780 & 0,361 & Valid \\
\hline & 2 & 0,492 & 0,361 & Valid \\
\hline & 3 & 0,793 & 0,361 & Valid \\
\hline & 4 & 0,407 & 0,361 & Valid \\
\hline & 5 & 0,835 & 0,361 & Valid \\
\hline & 6 & 0,839 & 0,361 & Valid \\
\hline & 7 & 0,649 & 0,361 & Valid \\
\hline & 8 & 0,716 & 0,361 & Valid \\
\hline & 9 & 0,754 & 0,361 & Valid \\
\hline & 10 & 0,420 & 0,361 & Valid \\
\hline & 11 & 0,508 & 0,361 & Valid \\
\hline & 12 & 0,602 & 0,361 & Valid \\
\hline & 13 & 0,492 & 0,361 & Valid \\
\hline & 14 & 0,549 & 0,361 & Valid \\
\hline & 15 & $-0,100$ & 0,361 & Tidak Valid \\
\hline & 16 & 0,602 & 0,361 & Valid \\
\hline & 17 & 0,602 & 0,361 & Valid \\
\hline & 18 & 0,670 & 0,361 & Valid \\
\hline & 19 & 0,447 & 0,361 & Valid \\
\hline \multirow{15}{*}{$\begin{array}{l}\text { Faktor-faktor yang menghambat } \\
\text { pembangunan }\end{array}$} & 1 & 0,476 & 0,361 & Valid \\
\hline & 2 & 0,696 & 0,361 & Valid \\
\hline & 3 & 0,462 & 0,361 & Valid \\
\hline & 4 & 0,304 & 0,361 & Tidak Valid \\
\hline & 5 & 0,474 & 0,361 & Valid \\
\hline & 6 & 0,434 & 0,361 & Valid \\
\hline & 7 & 0,382 & 0,361 & Valid \\
\hline & 8 & 0,446 & 0,361 & Valid \\
\hline & 9 & 0,607 & 0,361 & Valid \\
\hline & 10 & 0,487 & 0,361 & Valid \\
\hline & 11 & 0,474 & 0,361 & Valid \\
\hline & 12 & 0,474 & 0,361 & Valid \\
\hline & 13 & 0,383 & 0,361 & Valid \\
\hline & 14 & 0,346 & 0,361 & Tidak Valid \\
\hline & 15 & 0,474 & 0,361 & Valid \\
\hline \multirow{5}{*}{$\begin{array}{l}\text { Efektititas akuntabilitas pengelolaan } \\
\text { alokasi dana desa }\end{array}$} & 1 & 0,797 & 0,361 & Valid \\
\hline & 2 & 0,627 & 0,361 & Valid \\
\hline & 3 & 0,694 & 0,361 & Valid \\
\hline & 4 & 0,661 & 0,361 & Valid \\
\hline & 5 & 0,729 & 0,361 & Valid \\
\hline
\end{tabular}

Sumber: data yang diolah, 2018

\section{Hasil dan Pembahasan}

\subsection{Uji Validitas}

Uji validitas dilakukan terhadap seluruh butir pertanyaan dalam instrument, yaitu dengan cara mengkolerasikan skor tiap butir dengan skor totalnya. Hasil uji validitas pada penelitian ini dilakukan dengan membandingkan $r$ hitung dengan $r$ tabel, dimana $r$ tabel didapat dari $\mathrm{df}=\mathrm{N}$ -2 , sehingga ditemukan nilai $r$ tabel yaitu 0,361 .

Dari hasil penelitian ini didapatkan hasil berupa 36 data valid, 3 data tidak valid. 


\subsection{Uji Reliabilitas}

Uji reliabilitas digunakan untuk mengetahui sejauh mana suatu alat pengukur dapat dipercaya tetap konsisten jika dilakukan dua kali pengukuran atau lebih pada kelompok yang sama. Pengujian Cronbach Alpha digunakan untuk menguji tingkat keandalan (reability) dari masing-masing angket variabel. Dalam penelitian ini didapatkan nilai cronbach's alpha sebesar 0,815>0,6, sehingga variabel penelitian dinyatakan reliabel.

\subsection{Regresi Linier Berganda}

Persamaan regresi linier sebagai berikut:

$\mathrm{Y}=-7,021+0,186 \mathrm{X} 1+0,255 \mathrm{X} 2+\mathrm{e}$

Keterangan:

$\mathrm{X} 1$ = Pembangunan Desa

$\mathrm{X} 2$ = Faktor-faktor yang menghambat pengelolaan alokasi dana desa

\subsection{Uji Hipotesis}

\subsubsection{Uji t}

a. Dalam penelitian ini variabel pembangunan desa memiliki t hitung 3,778 > t tabel sebesar 2,05183, dan signifikansi sebesar 0,001 < alpha $=0,5$ artinya terdapat pengaruh yang signifikan antara variabel pembangunan desa (X1) terhadap akuntabilitas publik pengelolaan alokasi dana desa (Y).

b. Dalam penelitian ini variabel faktor-faktor yang menghambat pengelolaan alokasi dana desa (X2) memiliki t hitung 3,211 > t tabel sebesar 2,05283, dan signifikansi sebesar $0,003<$ alpha $=0,05$, artinya terdapat pengaruh yang signifikan antara variabel faktor-faktor yang menghambat pengelolaan alokasi dana desa (X2) terhadap akuntabilitas publik pengelolaan alokasi dana desa (Y).

\subsubsection{Uji F}

Dalam penelitian ini didapatkan $\mathrm{F}$ hitung sebesar 9,923 > F tabel sebesar 3,35. Dimana F tabel diperoleh dari $\mathrm{df}_{1}$ (horizontal) $=\mathrm{k}-1=3-$ $1=2$, dan $\mathrm{df}_{2}$ (vertical) $=\mathrm{n}-\mathrm{k}=30-3=27$, sehingga ditemukan $\mathrm{F}$ tabel dengan nilai 3,35. Sedangkan signifikansi $\mathrm{F}$ dalam penelitian ini adalah $0,001<$ alpha $=0,05$, artinya variabel pembangunan desa $\left(\mathrm{X}_{1}\right)$ dan faktor-faktor yang menghambat pengelolaan alokasi dana desa $\left(\mathrm{X}_{2}\right)$ secara simultan berpengaruh signifikan terhadap akuntabilitas publik pengelolaan alokasi dana desa (Y).

\subsection{Koefisien Determinasi}

Berdasarkan hasil uji $\mathrm{R}$ square diperoleh nilai $\mathrm{R}$ Square sebesar 0,424. Angka ini mengandung arti bahwa pembangunan desa $\left(\mathrm{X}_{1}\right)$ dan faktor-faktor yang menghambat pengelolaan alokasi dana desa berpengaruh $\left(\mathrm{X}_{2}\right)$ terhadap akuntabilitas publik pengelolaan alokasi dana desa (Y) sebesar 42,4,\% sedangkan sisanya $(100 \%-42,4 \%)=57,6 \%$ dipengaruhi oleh variabel lain yang tidak diteliti dalam penelitian ini.

\subsection{Pembahasan}

\subsubsection{Pengaruh Pembangunan Desa terhadap Akuntabilitas Publik Pengelolaan Alokasi Dana Desa}

Hasil uji hipotesis yang telah dilakukan antara pembangunan desa sebagai variabel $\mathrm{X}_{1}$ terhadap akuntabilitas publik pengelolaan alokasi dana desa, diperoleh nilai signifikansi t untuk variabel pembangunan desa sebesar $0,001<0,05$, sedangkan perbandingan antara $\mathrm{t}$ hitung dan $\mathrm{t}$ tabel adalah 3,778>2,05183. Hal ini menunjukan bahwa variabel pembangunan desa yang berisikan: perencanaan, pengorganisasian, pengarahan, serta pengendalian berpengaruh terhadap akuntabilitas publik pengelolaan alokasi dana desa, Desa Purwosari tahun 2017. Pembangunan desa menggambarkan perbandingan antara ekspektasi pemerintah Desa Purwosari dengan antusiasme masyarakat Desa Purwosari terkait penggunaan dana desa tahun 2017. Pembangunan desa dapat berjalan dengan baik apabila peran aparat desa dan masyarakat mendukung dengan baik mulai dari kegiatan musyawarah rencana pembangunan (Musrembang) sampai pengendalian pembangunan.

Penelitian ini mendukung penelitian Novindra Dwi Setiana dan Nur Laila Yuliana (2017) yang menyatakan bahwa peran perangkat desa berpengaruh positif terhadap akuntabilitas pengelolaan alokasi dana desa, dengan hasil penelitian $\mathrm{t}$ hitung lebih besar dari $\mathrm{t}$ tabel (5,715>1,989), dan signifikansi 0,000<0,05. Dan penelitian Novi anti ruru, Novi S. Budiarso serta 
Lintja kalagi yang menyatakan bahwa transparansi dalam pelaporan pengalokaasian dana desa dan partisipasi masyarakat berpengaruh dalam efektivitas akuntabilitas pengelolaan alokasi dana desa

\subsubsection{Pengaruh Faktor-Faktor yang} Menghambat Pengelolaan Alokasi Dana Desa terhadap Akuntabilitas Publik Pengelolaan Alokasi Dana Desa

Hasil uji hipotesis yang telah dilakukan antara fakto-faktor yang menghambat pengelolaan alokasi dana desa sebagai variabel $\mathrm{X}_{2}$ terhadap akuntabilitas publik penngelolaan alokasi dana desa, diperoleh signifikansi t untuk variabel faktor-faktor yang menghambat pengelolaan alokasi dana desa sebesar 0,003 < 0,05 , sedangkan perbandingan antara $\mathrm{t}$ hitung denngan t tabel adalah sebesar 3,211 > 2,05183. Hal ini menunjukan bahwa variabel faktor-faktor yang menghambat pengelolaan alokasi dana desa yang meliputi: sumber daya manusia, partisipasi masyarakat, dan informasi berpengaruh terhadap akuntabilitas publik pengelolaan alokasi dana desa, Desa Purwosari tahun 2017. Dalam penelitian ini, faktor-faktor yang menghambat pengelolaan alokasi dana desa menggambarkan mengenai pemahaman perangkat desa dan kemampuan tim pelaksana, partisipasi masyarakat dalam kegiatan pembangunan, serta informasi terkait pembangunan desa yang diberikan pemerintah desa. Profesionalisme tim pelaksana pembangunan desa sangat penting guna menghadapi masyarakat desa dengan berbagai karakter. Maka dalam pelaksanaan pembangunan desa perlu dimengerti kondisi sosial di Desa Purwosari, hal ini bertujuan agar masyarakat senantiasa ikhlas dalam berpartisipasi dalam kegiatan pembangunan desa. Serta pemerintah desa harus menyediakan informasi yang relevan mengenai pelaksanaan pembangunan.

Penelitian ini bertolak belakang dengan penelitian Novindra Dwi Setiana dan Nur Laila Yuliana (2017) yang menyatakan bahwa pemahaman perangkat desa tidak berpengaruh terhadap akuntabilitas pengelolaan alokasi dana desa dengan hasil penelitian $\mathrm{t}$ hitung lebih keci dari pada $t$ tabel $(1,397<1,989)$, dan signifikansi
$0,166>0,05$. Dan mendukung penelitian yang dilakukan oleh Hasniati yang menyataikan bahwa Sumber Daya Manusia (SDM) dan partisipasi masyarakat berpengaruh dalam pertanggungjawaban pengalokasian dana desa.

3.6.3 Pengaruh Pembangunan Desa dan Faktor-Faktor Yang Menghambat Pengalokasian Alokasi Dana Desa (ADD) terhadap Akuntabilitas Publik Pengelolaan Alokasi Dana Desa

Berdasarkan hasil uji simultan yang dilakukan dalam penellitian ini, ditemukan signifikansi F sebesar 0,001 <0,05, dan t hitung lebih besar dari pada $t$ tabel $(9,923>3,35)$. Hal ini menunjukan bahwa variabel pembangunan desa (X1) dan faktor-faktor yang menghambat pengalokasian alokasi dana desa berpegaruh secara simultan terhadap akuntabilitas publik pengelolaan alokasi dana desa. Dalam pertanggungjawaban pengalokasian dana desa tanggung jawab tidak hanya berupa laporan keuangan yang ditunjukan kepada masyarakat saja, tapi juga apakah pembangunan yang dilaksanakan dapat dirasakan lansung oleh masyarakat.

Penelitian ini mendukung penelitian yang dilakukan oleh Novindra Dwi Setiana dan Nur Laila Yuliani (2017) dengan hasil penelitian $t$ hitung lebih besar dari pada t tabel $(34,630>$ 3,11). Dan penelitian yang dilakukan oleh. Dan penelitian yang dilakukan oleh Novi Anti Ruru, Novi S. Bodiarso, Lintja Kalagi yang menyatakan bahwa Transparansi dalam pelaporan pengalokasian desa dan partisipasi masyarakat berpengaruh dalam efektivitas akuntabilitas pengelolaan dana desa.

\section{Kesimpulan dan Saran}

\subsection{Kesimpulan}

a. Secara parsial pembangunan desa berpengaruh terhadap efektivitas akuntabilitas publik pengelolaan alokasi dana desa, dengan nilai signifikansi $0,001<0,05$, dan perbandingan $\mathrm{t}$ hitung dengan sebesar $3,778>2,05183$. Sesuai dengan syarat diterimanya signifikansi uji parsial yaitu $\mathrm{t}$ hitung $>\mathrm{t}$ tabel. 
b. Secara parsial faktor-faktor yang menghambat pengalokasian dana desa berpengaruh terhadap efektivitas akuntabilitas publik pengelolaan alokasi dana desa, denga nilai signifikansi $0,003<0,05$, dan perbandingan antara $\mathrm{t}$ hitung dengan $\mathrm{t}$ tabel sebesar 3,211>2,05183. Sesuai dengan syarat diterimanya signifikansi uji parsial yaitu t hitung $>\mathrm{t}$ tabel.

c. Secara simultan pembangunan desa dan faktor-faktor yang menghambat pengalokasian alokasi dana desa berpengaruh signifikan terhadap efektivitas akuntabilitas publik pengelolaan alokasi dana desa, dengan nilai signifikansi $0,001<0,05$, dan perbandingan antara $\mathrm{F}$ hitung dengan $\mathrm{F}$ tabel sebesar 9,923 > 2,57. Sesuai dengan syarat diterimanya signifikansi uji parsial yaitu $\mathrm{F}$ hitung $>\mathrm{F}$ tabel.

\subsection{Saran}

Dari hasil penelitian, analisis data, pembahasan, dan kesimpulan yang telah diambil, maka dapat dikemukakan saran sebagai berikut:

a. Pemerintah desa hendaknya mengevaluasi ulang terkait perencanaan dan pelaksanaan pembangunan desa serta unsur-unsur yang terkandung didalamnya, agar kesadaran masyarakat lebih tergerak mengenai pembangunan desa, serta informasi mengenai pertanggungjawaban lebih transparan guna meghapuskan ketidakpercayaan masyarakat kepada pemerintah desa.

b. Bagi penelitian mendatang hendaknya instrumen penilitian lebih diperdalam dan dikembangkan lagi sehingga kemampuan pengukurannya lebih baik. Pada dasarnya masih ada banyak faktor-faktor lain yang mempengaruhi akuntabilitas publik pengelolaan alokasi dana desa yang tidak di gunakan pada penelitian ini.

\section{Daftar Pustaka}

Arikunto. 2013. Prosedur Penelitian Suatu Pendekatan Praktek. Jakarta: PT. Rineka cipta.
Ghozali,Imam. 2016.

Aplikasi

Analisis

Multivariete Dengan Program (IBM. SPSS).

Edisi 8. Badan Penerbit Universitas Diponegoro.

Handoko, Hani T. 2012. Manajemen Personalia \& Sumberdaya Manusia. Yogyakarta. BPFE Yogyakarta.

Hasniati. 2016. Model Akuntabilitas Pengelolaan Dana Desa. Jurnal Ilmiah Ekonomi dan Bisnis (Universitas Hasanuddin Makasar). http://www.ejournal.unhas.ac.id. (diakses: 15 Maret 2018).

Kumalasari, Deti. 2016. Transparansi dan Akuntabilitas Pemerintah Desa dalam Pengelolaan Alokasi Dana Desa (ADD). Studi kasus di Desa Bomo, Rogojampi, Banyuwangi. Jurnal Ilmiah Ekonomi dan Bisnis. (STIESIA Surabaya). http://www.ejournal.stiesia.ac.id.(diakses:1 Maret 2018).

Novindra, Nur. 2017. Pengaruh Pemahaman dan Peran Perangkat Desa Terhadap Akuntabilitas Pengelolaan Dana Desa. Jurnal Ekonomi dan Bisnis. (Universitas Muhammadiyah Magelang). http://www.jurnal.ummgl.ac.id. (diakses : 14 Maret 2018).

Novi, Bodiarso dan Lintja Kalagi. 2017. Analisis Penerapan Alokasi Dana Desa (ADD) dalam upaya Meningkatakan Pembangunan Desa (Desa Suwaan, Kecamatan Kalawat, Kabupaten Minahasa Utara"). Jurnal Ekonomi dan Bisnis. Universitas Sam Ratulangi. http://www.ejournal.unsrat.ac.id. (diakses: 2 Maret 2018).

Sugiyono. 2017. Metode Penelitian Kuantitatif Kuantitatif Kualitatif dan R\&D. Bandung : Alfabeta.

Sulastri, Novia. 2016. Efektivitas Pengelolaan Alokasi Dana Desa (ADD) dalam Meningkatakan Pembangunan Fisik Desa Lakapodo, Kecamatan Watopute, Kabupaten Muna. Jurnal Ekonomi dan Bisnis. Universitas Halu Oleo, Kendari. http://www.sitedi.uho.ac.id (diakses: 2 Maret 2018).

Tulus T.H. Tambunan. 2003. Perekonomian Indonesia. Jakarta Ghalia Indonesia

Widjaja. 2010. Komunikasi: Komunikasi dan hubungan masyarakat. Jakarta: Bumi. Aksara. 